\title{
Lead-based systems as suitable anode materials for Li-ion batteries
}

\author{
M. Martos, J. Morales, L. Sánchez* \\ Departamento de Química Inorgánica e Ingeniería Química, Facultad de Ciencias, Campus de Rabanales, Edificio C-3, Universidad de Córdoba, 14071 \\ Córdoba, Spain
}

Received 31 July 2002

\begin{abstract}
Three lead-based materials formed by $\mathrm{PbO}_{2}, \mathrm{PbO}$ and $\mathrm{Pb}$ as main phases were prepared by following different synthetic procedures and tested as anodic materials in $\mathrm{Li}$-ion batteries by using potentiostatic and galvanostatic methods. While the reduction of $\mathrm{Pb}(\mathrm{IV})$ to $\mathrm{Pb}(\mathrm{II})$ takes place in a single step, that of $\mathrm{Pb}(\mathrm{II})$ to $\mathrm{Pb}$ is a complex process involving several steps. Both reduction reactions are irreversible. Lead, whether electrochemically or chemically formed, undergoes an electrochemical reaction with lithium that over the $1.0-0.0 \mathrm{~V}$ potential range yields $\mathrm{Li}_{x} \mathrm{~Pb}$ alloys $(0 \leq x \leq 4.4)$. The anodic and cathodic potentiostatic curves exhibit various signals that account for: (i) the formation of different intermediates with variable lithium contents; (ii) the reversibility of the alloying/de-alloying processes; (iii) the increase in complexity of such processes as the oxidation state of lead in them decreases. This results in capacity fading with cycling, particularly in the samples having $\mathrm{Pb}$ as the main component. One way of avoiding the capacity loss on cycling involves depositing the active material on lead sheets from spraying suspensions. These coatings exhibit a good capacity retention, which can be ascribed to the formation of a $\mathrm{Li}_{x} \mathrm{~Pb}$ layer at the active material/substrate interface that facilitates electron and ion transfer across the electrode.
\end{abstract}

(C) 2002 Elsevier Science Ltd. All rights reserved.

Keywords: Lead; Lead oxide; Rechargeable lithium batteries; Anodic materials

\section{Introduction}

Lithium-based alloys are currently regarded as promising candidates for use as negative electrode materials in Li-ion batteries [1]. These materials were examined in the $1970 \mathrm{~s}$ as alternatives to elemental lithium by researchers working on batteries based on molten salt electrolytes and operating at temperatures above the melting point of lithium [2].

The inception of the Stalion ${ }^{\circledR}$ lithium ion cell [3], developed by Fuji Photo Film Celltec. Co. (Japan), arouse new interest on these alloy-based compounds. The Stalion cell uses an amorphous tin-based composite oxide as anode material. During operation an alloy reaction between lithium and tin takes place. The high \footnotetext{
621

* Corresponding author. Tel.: +34-957-218-620; fax: +34-957-218-

E-mail address: iq2sagrl@uco.es (L. Sánchez).
}

reversibility of this alloying process allows one to obtain optimal gravimetric and volumetric specific capacity values.

In the last 5 years, intensive research has been devoted to elucidate the behaviour of tin, tin-based intermetallics and composites in lithium cells [4-7]. Also, much research has focussed on the development of new systems capable of alloying with lithium, namely: $\mathrm{Bi}$ [8], $\mathrm{Mg}$ [9], $\mathrm{Sb}$ [10], $\mathrm{Si}$ [11] and $\mathrm{Zn}$ [12]. Lead composite materials, in particular, can undergo reversible $\mathrm{Li}$ alloying/de-alloying over the potential range of $0.0-1.5$ $\mathrm{V}[13,14]$.

In previous work, we showed the usefulness of $\mathrm{PbO}$ thin films as anodes in lithium secondary batteries [15]. The films were obtained by heating a lead acetate precursor previously deposited onto a lead substrate. Their electrochemical properties were found to be affected by factors such as particle size, phase composition and the substrate/active material interface. In this 
work, we examined various lead compounds (lead itself included) obtained by different synthesis procedures as electrodes in lithium cells, with special emphasis on the relationship between their physico-chemical and electrochemical properties.

\section{Experimental}

One of the purposes of this work was to study the electrochemical properties of the $\mathrm{Li}_{x} \mathrm{~Pb}$ alloys obtained from precursors of lead in different oxidation states (viz. 0 , II and IV). To this end, three different samples were prepared via the following aqueous precipitation procedures:

- Sample A. A brown precipitate was obtained by hydrolysing $2.0 \mathrm{~g}$ of $\mathrm{Pb}\left(\mathrm{CH}_{3} \mathrm{COO}\right)_{4}$. The product was filtered, washed several times with distilled water and dried at $80{ }^{\circ} \mathrm{C}$ for $24 \mathrm{~h}$.

- Sample B. A $0.5 \mathrm{M} \mathrm{Na}_{2} \mathrm{CO}_{3}$ solution was poured dropwise into a $0.5 \mathrm{M} \mathrm{Pb}\left(\mathrm{NO}_{3}\right)_{2} \cdot 3 \mathrm{H}_{2} \mathrm{O}$ solution under continuous stirring. The white precipitate formed was separated by centrifugation at $3000 \mathrm{rpm}$ for $10 \mathrm{~min}$, dried at $110{ }^{\circ} \mathrm{C}$ for $24 \mathrm{~h}$ and then calcined in the air at $320{ }^{\circ} \mathrm{C}$ for $24 \mathrm{~h}$.

- Sample C. A volume of $25 \mathrm{ml}$ of a $0.1 \mathrm{M} \mathrm{Pb}\left(\mathrm{NO}_{3}\right)_{2}$. $3 \mathrm{H}_{2} \mathrm{O}$ solution was mixed with $25 \mathrm{ml}$ of a $4 \mathrm{M} \mathrm{NaOH}$ solution in a flask furnished with a Bunsen valve. Once the solution was warmed at $80{ }^{\circ} \mathrm{C}, 60 \mathrm{mg}$ of aluminium powder was added. The black precipitate thus obtained was rapidly washed with water, dried and kept under an argon atmosphere for further characterization.

$\mathrm{X}$-ray diffraction (XRD) patterns were recorded on a Siemens D5000 X-ray diffractometer, using $\mathrm{Cu} \mathrm{K \alpha}$ radiation and a graphite monochromator. Scanning electron microscopy (SEM) images were obtained on a Jeol JMS 6400 microscope.

Electrochemical experiments were carried out in twoelectrode cells, using lithium as anode. The electrolyte used was $1 \mathrm{M}$ anhydrous $\mathrm{LiPF}_{6}$ in a 1:1 mixture of ethylene carbonate (EC) and dimethyl carbonate (DMC). The electrode pellets $(7 \mathrm{~mm}$ diameter) were prepared by pressing, in an stainless steel grid, ca. $4 \mathrm{mg}$ of active material with polytetrafluoroethylene (PTFE) (5 wt.\%), and acetylene black (10 wt.\%) at 4 ton. Lithium foil was cut into circles $7 \mathrm{~mm}$ in diameter. Electrochemical measurements were made with a MacPile II potentiostat-galvanostat. Galvanostatic charge/ discharge curves were obtained at a current density of $0.25 \mathrm{~mA} \mathrm{~cm}^{-2}$. Step potential electrochemical spectroscopy (SPES) spectra were recorded in $10 \mathrm{mV} \mathrm{h}^{-1}$ steps.

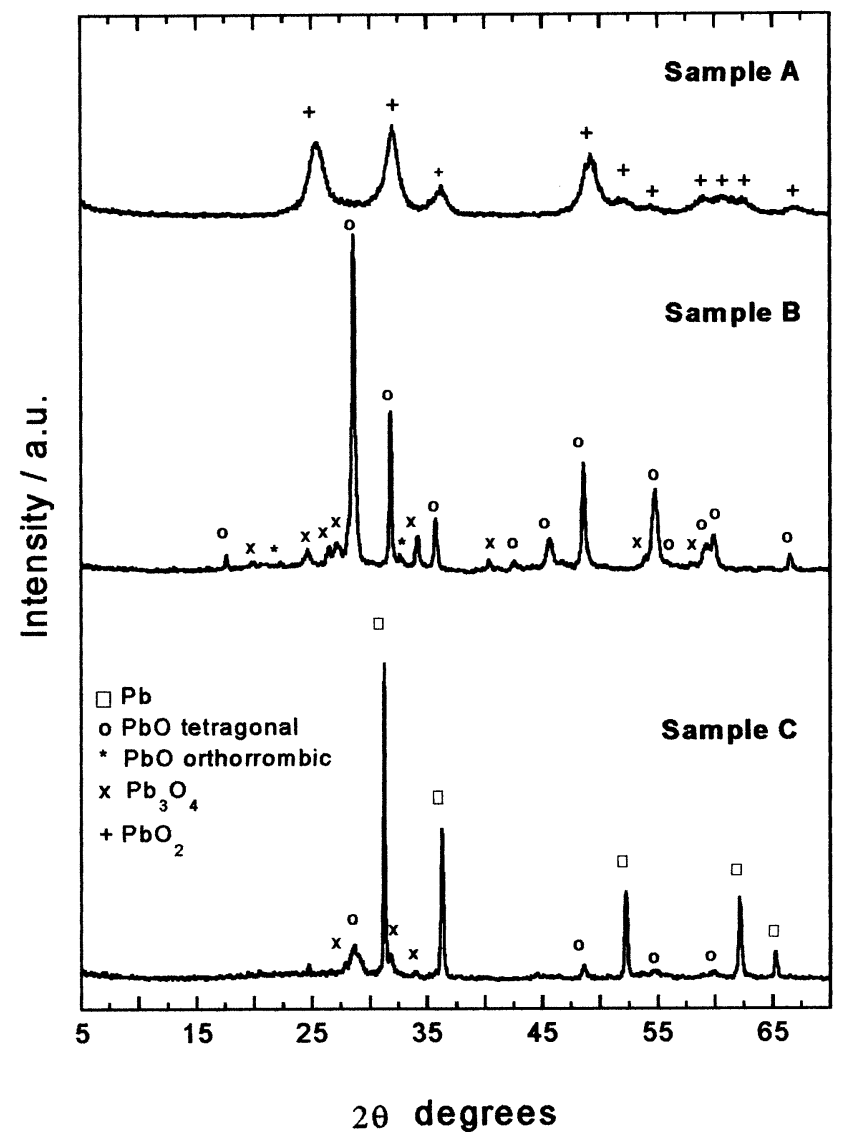

Fig. 1. XRD patterns for the three lead-based systems.

\section{Results and discussion}

Fig. 1 shows the XRD patterns for the three samples studied. Sample A was identified as $\beta-\mathrm{PbO}_{2}$ (Fig. 1a). Sample B consisted of $\alpha-\mathrm{PbO}$ as the dominant phase plus impurities of $\beta-\mathrm{PbO}$ and red lead, $\mathrm{Pb}_{3} \mathrm{O}_{4}$ (Fig. 1b). Sample $\mathrm{C}$ was composed of lead and contained small amounts of $\alpha-\mathrm{PbO}$ and $\mathrm{Pb}_{3} \mathrm{O}_{4}$ (Fig. 1c). Sample compositions were determined from the corresponding XRD patterns, using PEAKS ${ }^{\circledR}$ software [16]. The results are shown in Table 1.

As can be seen from the SEM images in Fig. 2, the synthetic procedures used resulted in differences in particle morphology. Thus, sample A crystallized as large lamellar particles of non-uniform size distribution ranging from 2 to $20 \mu \mathrm{m}$ in size. Particle shape and size

Table 1

Contents in lead compounds of the samples studied

\begin{tabular}{llcll}
\hline Compound & \multicolumn{4}{l}{ Lead oxide $(\%$ weight $)$} \\
& $\mathrm{PbO}_{2}$ & $\mathrm{~Pb}_{3} \mathrm{O}_{4}$ & $\mathrm{PbO}$ & $\mathrm{Pb}$ \\
\hline Sample A & 100 & - & - & - \\
Sample B & - & 11 & 89 & - \\
Sample C & - & 9 & 25 & 66 \\
\hline
\end{tabular}



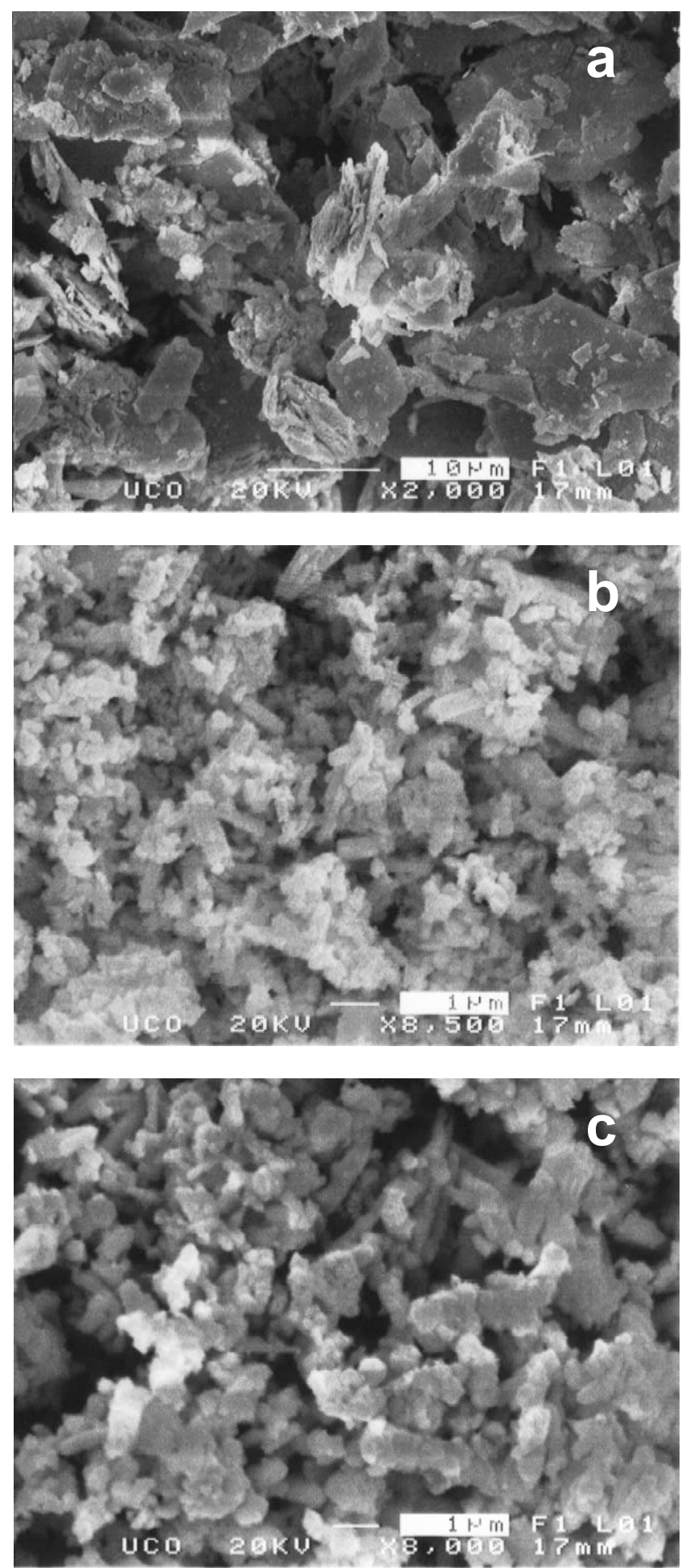

Fig. 2. SEM images obtained from (a) sample A, (b) sample B, (c) sample C

distribution were more uniform in samples B and C. Sample B particles were rod-shape and less than $1 \mu \mathrm{m}$ long whereas sample $\mathrm{C}$ particles were rounder and close to $1 \mu \mathrm{m}$ in size. The small particle size of the latter two samples may be the origin of their easy oxidation and tendency to occur as multi-phase systems (see Table 1).

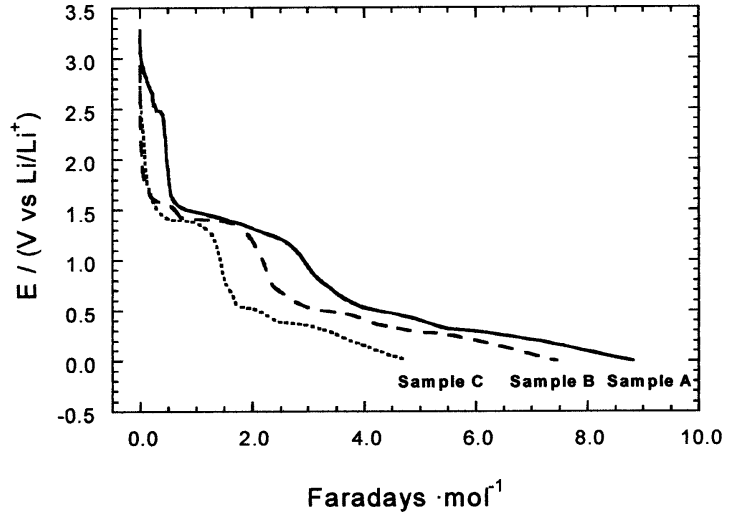

Fig. 3. First-discharge galvanostatic curve for the three cells made from the lead-based systems.

Fig. 3 compares the first galvanostatic discharge curves for the three lead-based compounds. They were analysed over two potential ranges, namely: $3.0-0.8$ and $0.8-0.0 \mathrm{~V}$. The higher potential region corresponds to the reduction of lead(IV) and (II) to metal lead. As expected, differences in curve profiles exposed differences in sample composition. Thus, sample A exhibited a two-step curve with two pseudo-plateaux at 2.5 and $1.4 \mathrm{~V}$, consistent with reported discharge curves for $\beta$ $\mathrm{PbO}_{2}$ [17]. Sample B exhibited two steps at 1.6 and $1.4 \mathrm{~V}$ the origin of which could be the presence of two different phases in this system [18]. The presence of substantial amount of lead oxides in sample C (see Table 1) could be also the origin of the plateau observed between 1.6 and $1.2 \mathrm{~V}$. The curves are more similar in shape below $0.8 \mathrm{~V}$. In this potential region, various steps are observed that correspond to the formation of different $\mathrm{Li}_{x} \mathrm{~Pb}$ alloys $(1.0<x<4.4)$ [19]. The overall process occurring in the two potential ranges can be summarized in the following reactions:

$\mathrm{PbO}_{x}+2 x \mathrm{Li}^{+} \rightarrow x \mathrm{Li}_{2} \mathrm{O}+\mathrm{Pb}$

$\mathrm{Pb}+4.4 \mathrm{Li}^{+} \Leftrightarrow \mathrm{Li}_{4.4} \mathrm{~Pb}$

When the electrochemical process is reversed from a starting value of $0.0 \mathrm{~V}$, strong polarization is observed in the charge curve above $1.0 \mathrm{~V}$, which suggests that reaction (1) is irreversible [20]. Accordingly, 8.4, 6.4 and 4.4 lithium equivalents per mole of compound could be discharged for pure $\mathrm{PbO}_{2}, \mathrm{PbO}$ and $\mathrm{Pb}$, respectively. The values obtained from the discharge curves in Fig. 3 are fairly consistent with the previous assertion. Thus, sample A, consisting of $\mathrm{PbO}_{2}$, reacts with 8.8 lithium equivalents per mole $(4 \%$ more than stoichiometric value). This difference is quite acceptable, taking into account the possibility of amorphous particles undetected by X-ray. However, one question remains unanswered namely $[17,18]$ : the presence of the short plateau at $2.5 \mathrm{~V}$, that might be assigned to the reaction $\mathrm{Pb}$ (IV) $\rightarrow \mathrm{Pb}$ (II) and accounts for only 0.5 lithium equivalents per mole. In order to shed some light on 
this apparent inconsistency, 'ex-situ' XRD patterns for lithiated samples were recorded at different discharge depths. With the aim of ensuring adequate quality in the XRD patterns, measurements were made on highly crystalline commercial $\mathrm{PbO}_{2}$, the discharge curve for which exhibited the same features as those for sample A. A significant increase in background-to-signal ratio was observed just below the $2.5 \mathrm{~V}$ plateau as the likely result of lithium insertion causing the $\mathrm{PbO}_{2}$ framework to collapse (see Fig. 4). Only weak peaks corresponding to $\mathrm{PbO}_{2}$ were identified at such a discharge depth. Amorphization of the sample was complete when 2 lithium equivalents per mole were consumed, and reflections corresponding to metal lead where only observed upon insertion of 4 lithium equivalents per mole. No evidence of the formation of reduced phases such as $\mathrm{Pb}_{3} \mathrm{O}_{4}$ or $\mathrm{PbO}$ was found. Nor are the $\mathrm{X}$-ray data consistent with a model based on the formation of an intercalated phase $\mathrm{Li}_{x} \mathrm{PbO}_{2}$ retaining the main structural characteristics of the host. Thus, neither plateau in the discharge curve that describes the reduction of $\mathrm{Pb}(\mathrm{IV})$ to $\mathrm{Pb}(\mathrm{II})$ in lithium cells leads to crystalline phases; rather, they result from amorphization of the pristine compound. In previous work, Bicelli et al. [21] proposed a two-stepmechanism $\left(\mathrm{Pb}_{3} \mathrm{O}_{4} \rightarrow \mathrm{PbO} \rightarrow \mathrm{Pb}\right)$ for the electrochemical discharge of $\mathrm{Li} / \mathrm{Pb}_{3} \mathrm{O}_{4}$ cells, using XPS analysis of the

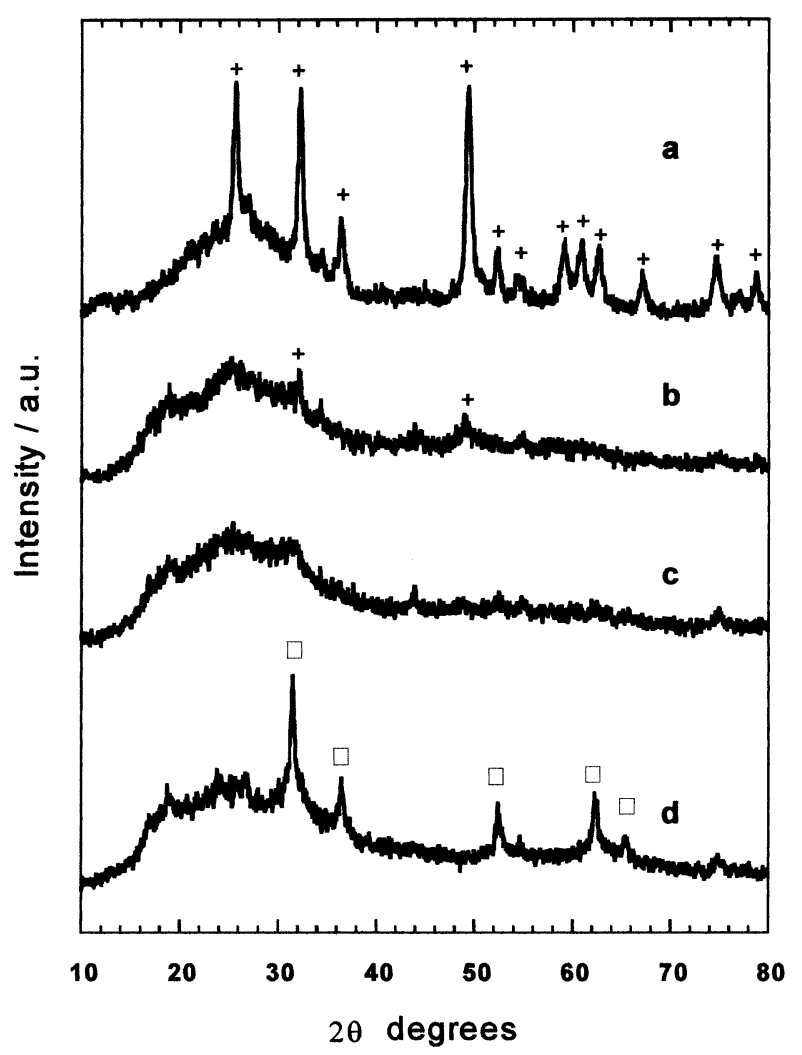

Fig. 4. XRD patterns for commercial $\mathrm{PbO}_{2}$ (a) and the same material upon lithium discharge up to 0.15 (b), 2.0 (c) and 4.0 (d). [Phase identification: (+) $\mathrm{PbO}_{2},(\square) \mathrm{Pb}$. discharge products [21]. Consistent with these results and our own X-ray data, an amorphous $\mathrm{PbO}$ phase can be assumed to occur as an intermediate in the reduction of $\mathrm{PbO}_{2}$.

Similarly consistent discharge depth values were obtained for samples B and C by using the composition data of Table 1 for calculation.

Complementary information about the redox processes involved in the first discharge curve can be derived from the SPES curves of Fig. 5. Several peaks are observed at $2.6,1.8-1.75,1.5,1.35-1.30,1.22,0.7$, 0.22 and $0.09 \mathrm{~V}$ that are typical of the different electrochemical processes undergone by the material and the ascription of which raises some difficulties, namely:

The peak at highest potential only appears in sample $\mathrm{A}$ and corresponds to the reduction process $\mathrm{Pb}(\mathrm{IV}) \rightarrow$ $\mathrm{Pb}(\mathrm{II})$.
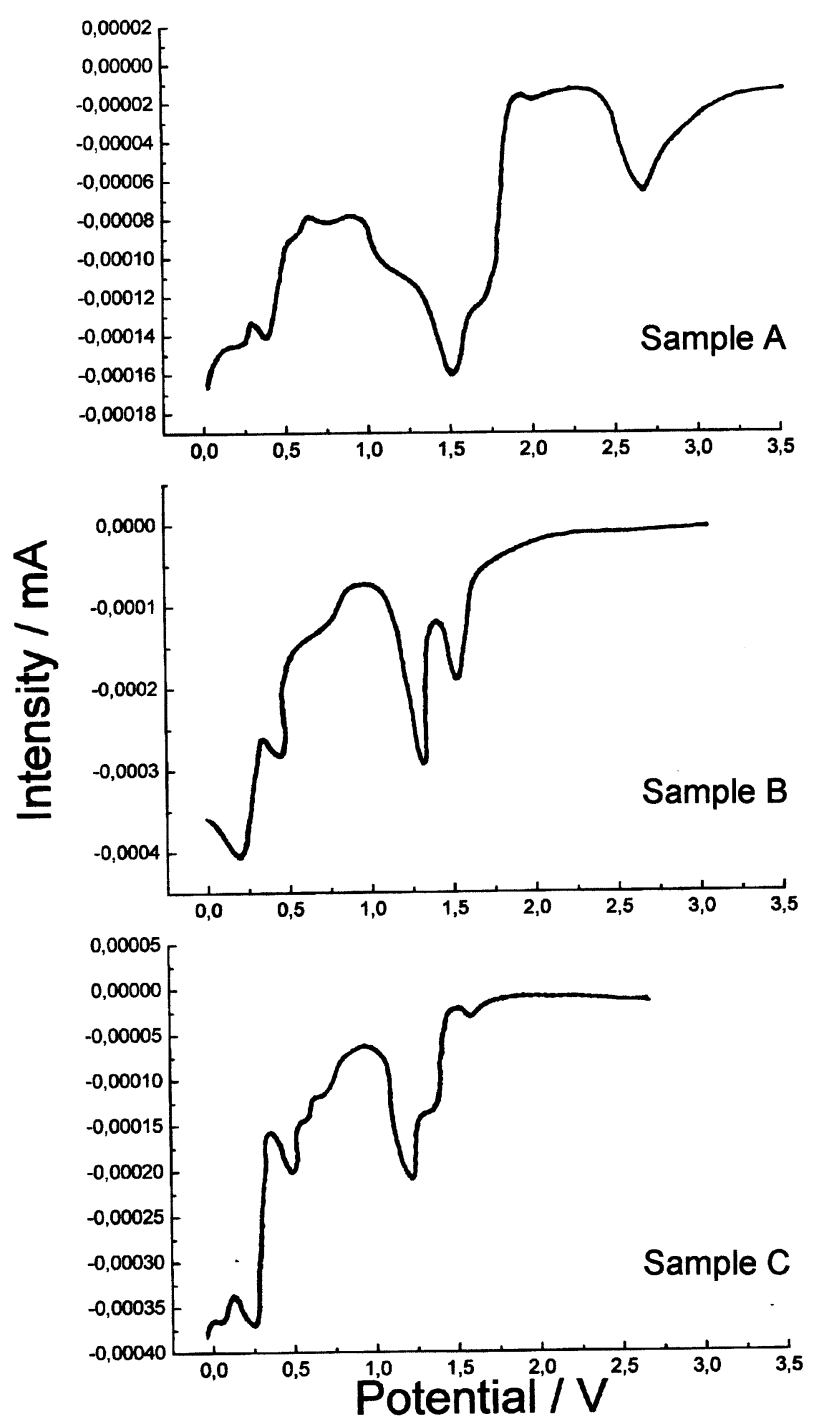

Fig. 5. SPES curves for the cells made from the lead-based systems. 
The shoulder of sample B at $1.8 \mathrm{~V}$, and that at $1.75 \mathrm{~V}$ in sample $\mathrm{A}$, could be associated to the reduction of $\mathrm{Pb}$ (IV) present in $\mathrm{Pb}_{3} \mathrm{O}_{4}$. However, the discharge curve for pure $\mathrm{Pb}_{3} \mathrm{O}_{4}$ yields an extended peak below 1.6 V [21].

The peaks between 1.6 and $1.20 \mathrm{~V}$ are common to all samples, albeit with variable intensity. They can be ascribed to the $\mathrm{Pb}(\mathrm{II}) \rightarrow \mathrm{Pb}(0)$ reduction process and reflect the fact that this transformation takes place through some intermediate, (e.g. $\mathrm{Pb}(\mathrm{I}))$ [17].

The low-potential region exhibits several peaks corresponding to the formation of $\mathrm{Li}_{x} \mathrm{~Pb}$ alloys (Fig. 5). There are some discrepancies regarding the $\mathrm{Li}-\mathrm{Pb}$ system. Thus, while Pearson [22] suggested the presence of at least six intermetallic compounds (viz. LiPb, $\mathrm{Li}_{5} \mathrm{~Pb}_{2}, \mathrm{Li}_{3} \mathrm{~Pb}, \mathrm{Li}_{10} \mathrm{~Pb}_{3}, \mathrm{Li}_{7} \mathrm{~Pb}_{2}$ and $\left.\mathrm{Li}_{4} \mathrm{~Pb}\right)$, Huggins [23], in describing the system in terms of composition ranges $\left(\mathrm{Li}_{x} \mathrm{~Pb}\right)$, identified four potential plateaux at $0.601,0.449,0.374$ and $0.292 \mathrm{~V}$ over the composition range $0<x<4.5$ (viz. $\mathrm{LiPb}, \mathrm{Li}_{2.6} \mathrm{~Pb}, \mathrm{Li}_{3} \mathrm{~Pb}, \mathrm{Li}_{3.5} \mathrm{~Pb}$, $\mathrm{Li}_{4.4} \mathrm{~Pb}$ ). Our results are somewhat more consistent with those of Huggins. In fact, at the first discharge, we found three peaks at 0.7 (very weak), $0.45-0.35$ and 0.2 $\mathrm{V}$, which are slightly different from the values for the above described plateaux. Kinetic contributions inherent in the non-steady electrochemical techniques used might account for the discrepancy.

Fig. 6 illustrates the second discharge and charge of the three systems over the potential range $0.0-1.0 \mathrm{~V}$. These curves are slightly different in shape from those of Fig. 5. Also, the significant differences between them warrant some comment. The general trend is an increase in complexity from sample A to C. Table 2 shows the potential peaks of the cathodic and anodic waves for sample B together with the corresponding assignation to the compositions of the lithium-lead alloy formed according to Huggins [23]. The anodic curve for sample $\mathrm{C}$ exhibits two additional peaks at 0.37 and $0.42 \mathrm{~V}$. In any case, the reversibility of the electrochemical process seems to be more prominent in samples A and B, which exhibit greater consistency between their anodic and cathodic waves.

The differences in particle morphology, size and composition could account for these electrochemical results. Thus, a large volume increase is involved in the formation of $\mathrm{a}^{2} \mathrm{i}_{x} \mathrm{~Pb}$ alloy from $\mathrm{Pb}$ (Table 2) with subsequent cracking and crumbling of the material. This rupture can cause a loss of electrical contact hindering the reversibility of the electrochemical reaction with lithium. As reported for tin-based anodes [4], the presence of an ionic conductive $\mathrm{Li}_{2} \mathrm{O}$ matrix hinders the aggregation of $\mathrm{Pb}$ atoms into large coherent domains and enhances the alloying/de-alloying processes. $\mathrm{A} \mathrm{Li}_{2} \mathrm{O} / \mathrm{Pb}$ ratio of $2,1.1$ and 0.31 is calculated for samples $\mathrm{A}, \mathrm{B}$, and $\mathrm{C}$, respectively. The presence of lead in sample $\mathrm{C}$, with the subsequent decrease in $\mathrm{Li}_{2} \mathrm{O}$ / $\mathrm{Pb}$ ratio, could account for its differential electrochemi-
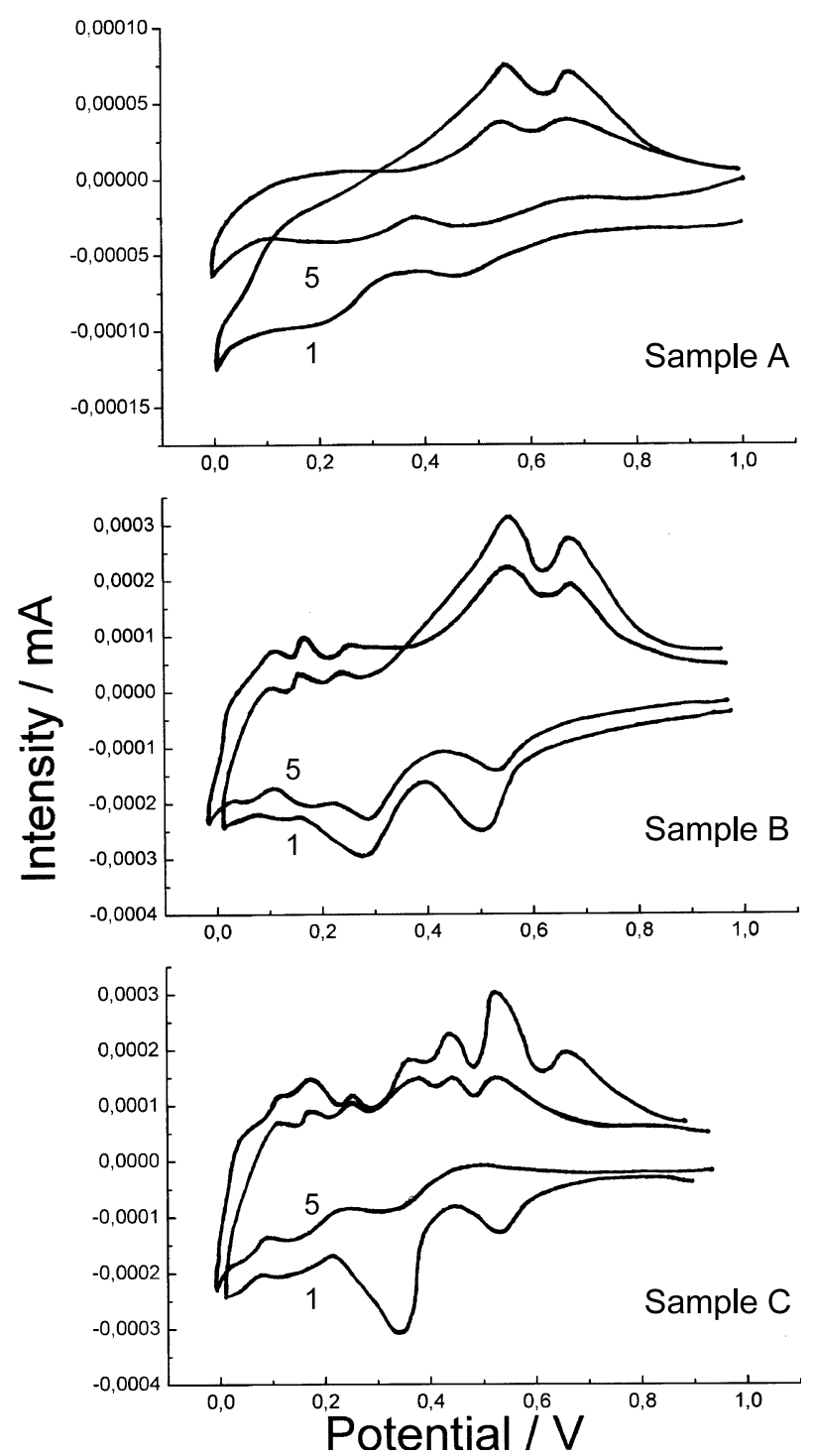

Fig. 6. SPES curves cycled over the range $0.0-1.0 \mathrm{~V}$. Arabic numerals denote cycle numbers.

Table 2

Lithium-lead alloys formed and observed potentials of the alloying and de-alloying processes

\begin{tabular}{llll}
\hline $\begin{array}{l}\text { Lead } \\
\text { alloy }\end{array}$ & $\begin{array}{l}\text { Cathodic signal } \\
(\mathrm{V})\end{array}$ & $\begin{array}{l}\text { Anodic signal } \\
(\mathrm{V})\end{array}$ & $\begin{array}{l}\mathrm{Li}_{x} \mathrm{~Pb} / \mathrm{Pb} \text { volume ra- } \\
\text { tio }\end{array}$ \\
\hline $\mathrm{Pb}$ & - & - & 1 \\
$\mathrm{LiPb}$ & 0.53 & 0.66 & 1.46 \\
$\mathrm{Li}_{2.6} \mathrm{~Pb}$ & $0.30-0.26$ & 0.54 & 2.3 \\
$\mathrm{Li}_{3.0} \mathrm{~Pb}$ & - & 0.24 & 2.46 \\
$\mathrm{Li}_{3.5} \mathrm{~Pb}$ & 0.12 & 0.15 & 2.76 \\
$\mathrm{Li}_{4.4} \mathrm{~Pb}$ & 0.05 & 0.10 & 3.30
\end{tabular}

cal response, particularly the strong peak of the cathodic curve at $0.31 \mathrm{~V}$ and the greater complexity of the anodic wave. Thus, new peaks at 0.38 and $0.42 \mathrm{~V}$ appear in the 
region where the $\mathrm{Li}_{3.0} \mathrm{~Pb} \rightarrow \mathrm{Li}_{2.6} \mathrm{~Pb} \rightarrow \mathrm{LiPb}$ transformation starts. In the fifth discharge, the peak at $0.31 \mathrm{~V}$ is significantly weaker, which suggests a loss reversibility in the electrochemical reactions. In fact, a further charge results in a profile that is rather different from that of a discharge (Fig. 6c). These peaks are thus undesirable, and, similarly to those reported for tin-based compounds [4], they can be associated with the presence of bulk $\mathrm{Li}-\mathrm{Pb}$ alloy phases following aggregation of lead. Sample B, which consists mainly of $\mathrm{PbO}$, possesses an increased $\mathrm{Li}_{2} \mathrm{O} / \mathrm{Pb}$ ratio. This has two major implications, namely: (i) greater similarity between the anodic and cathodic waves; and (ii) the retention of the peak intensity in the fifth discharge (Fig. 6b). In sample A both curves only retain the two main peaks (Fig. 6a). The greater amount of $\mathrm{Li}_{2} \mathrm{O}$ matrix formed from $\mathrm{PbO}_{2}$ facilitates to the transformation between the different lithium lead alloys and only the peaks corresponding to the alloying/de-alloying of $\mathrm{LiPb}$ into $\mathrm{Li}_{2.6} \mathrm{~Pb}$ - where lithium exhibits a better diffusivity - are well-defined.

Fig. 7 shows the variation of the specific capacity of the cells, established from galvanostatic measurements, as a function of the number of cycles. Although capacity faded on cycling the three samples, irrespective of their phase composition, the general trend was consistent with the SPES curves of Fig. 6 and with the above model based on the favourable effect on the reversibility of the alloying/de-alloying processes arising from the diluent effect attributed to the $\mathrm{Li}_{2} \mathrm{O}$ inert matrix. The highest specific capacities were those delivered by the cells made from samples $\mathrm{A}$ and $\mathrm{B}$, which had a high $\mathrm{Li}_{2} \mathrm{O}$ content once the lithium alloys began to form. In contrast, the cell made from sample $\mathrm{C}$, with a lower $\mathrm{Li}_{2} \mathrm{O}$ content, provided the lowest capacity values.

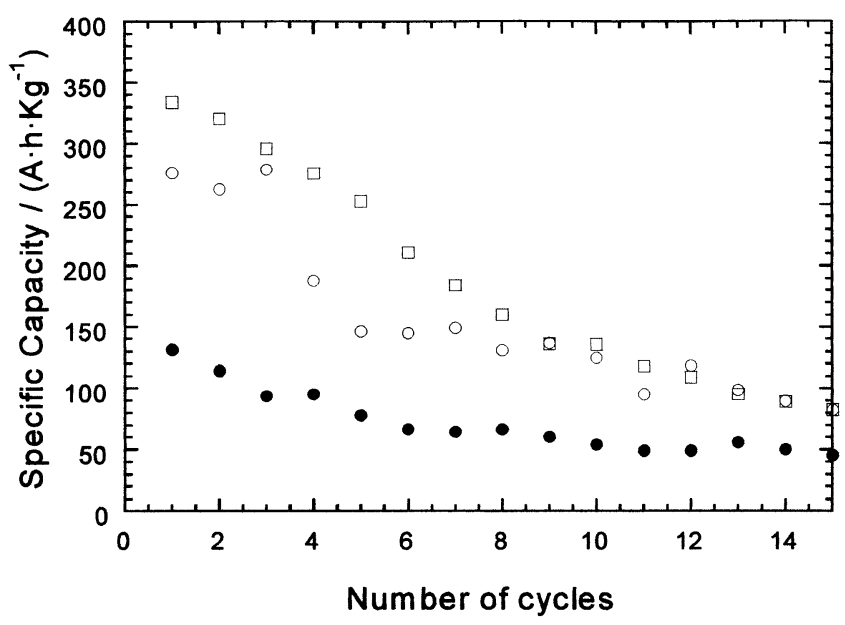

Fig. 7. Variation of the delivered specific capacity with cycling. Data were obtained from galvanostatic measurements $[(\square)$ sample $A,(\bigcirc)$ sample $B,(\bullet)$ sample $C]$.
The electrochemical performance of a lead-based anode can be improved by depositing the material onto a $\mathrm{Pb}$ substrate as reported elsewhere [15]. Good retention capacity on cycling was observed for $\mathrm{PbO}$ films obtained by pyrolysis of $\mathrm{Pb}\left(\mathrm{CH}_{3}-\mathrm{COO}\right)_{2}$ solutions sprayed on lead foils. In this case, particle adherence to the substrate was improved after the alloying/de-alloying processes as a result of the formation of a $\mathrm{Li}_{x} \mathrm{~Pb}$ thin film at the active mass/substrate interface. This layer acts as a binder that increases the adhesion of the active material to the substrate, thus facilitating charge transfer between the particles and substrate.

These measurements were made on sample B, which contained $\mathrm{PbO}$ as the main component. Coating was performed by using spray method described elsewhere [24]: an aqueous suspension of sample B was sprayed onto high-purity lead sheets (Strem, $0.25 \mathrm{~mm}$ thick). The substrate was kept at $175{ }^{\circ} \mathrm{C}$ during deposition and the electrode was subsequently kept at $80{ }^{\circ} \mathrm{C}$ for $24 \mathrm{~h}$ before use. A uniform coating was obtained with no appreciable differences in particle size or shape.

The cycling properties of these coatings are illustrated in Fig. 8; specific capacity values were corrected for the capacity delivered by the substrate, which was determined by using the uncoated sheet as electrode. Under these conditions, the lead-based material exhibits two advantages over the bulk system, namely: better retention of the specific capacity and a greater average value (350 $\mathrm{A} \mathrm{h} \mathrm{kg}^{-1}$ ) over the first 25 cycles. The improved electrochemical performance can be ascribed to: (i) good dispersion of particles, which help avoid cracking and crumbling; and (ii) the presence of a $\mathrm{Li}_{x} \mathrm{~Pb}$ layer at the active material/substrate interface that helps particles bind to the electrode and sustains the electronic and ionic conductivity of the sample.

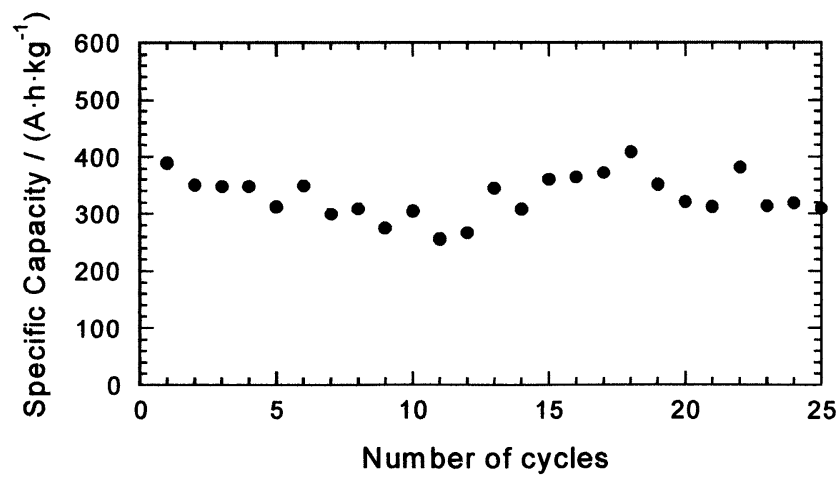

Fig. 8. Delivered specific capacity for the cell made from sample B deposited onto a lead sheet. The cell was cycled over the range $0.0-1.0$ V. Specific capacity values were corrected for the capacity delivered by the substrate, which was determined by using the uncoated sheet as electrode. 


\section{Conclusions}

We examined the electrochemical performance of various lead-based systems as anodic materials for Liion cells. Three different procedures were used to obtain three different samples the main component of which was $\mathrm{PbO}_{2}, \mathrm{PbO}$ and $\mathrm{Pb}$, respectively, the first sample consisted of micron-sized particles and the other two of sub-micrometric particles. SPES curves allowed the different steps that describe the reactivity of these phases towards lithium to be established. The most interesting electrochemical reaction as regards their usefulness as anodic materials is the formation of reversible $\mathrm{Li}_{x} \mathrm{~Pb}$ alloys, together with the irreversible formation of $\mathrm{Li}_{2} \mathrm{O}$ in the reduction of lead oxides during the first discharge. The presence of this species enhances the cycling properties of the electrode by acting as a dispersion agent, preventing the formation of large $\mathrm{Pb}$ aggregates and increasing the reversibility of alloying/de-alloying processes. Thus, the best electrochemical response was that of samples composed of lead oxides; by contrast, the cell made from the sample with a high lead content delivered a lower capacity. However, the specific capacity of these lead-based compounds fades on cycling. This shortcoming was circumvented by depositing the active material on lead sheets. The efficient adherence of particles to the substrate, via a mechanism that resembles curing of the positive plate of the lead-acid battery, may account for the good capacity retention observed.

\section{Acknowledgements}

This work was supported by Spain's Ministry of Education, Culture and Sports (FD97-0839-C03-03) and Junta de Andalucía (Group FQM-175).

\section{References}

[1] J.O. Besenhard, J. Yang, M. Winter, J. Power Sources 68 (1997) 87.

[2] R.A. Huggins, J. Power Sources 81-82 (1999) 13.

[3] Y. Idota, M. Mishima, M. Miyaki, T. Kubota, T. Misayaka, Eur. Pat. Appl. 651450 A1 950503.

[4] I.A. Courtney, J.R. Dahn, J. Electrochem. Soc. 144 (1997) 2045.

[5] J. Morales, L. Sánchez, J. Electrochem. Soc. 146 (1999) 1640.

[6] K.D. Kepler, J.T. Vaughey, M.M. Thackeray, J. Power Sources 81-82 (1999) 383.

[7] O. Mao, J.R. Dahn, J. Electrochem. Soc. 146 (1999) 423.

[8] O. Crosnier, X. Devaux, T. Brousse, P. Fragnaud, D.M. Schleich, J. Power Sources 97-98 (2001) 188.

[9] Z. Shi, M. Liu, D. Naik, J.L. Gole, J. Power Sources 92 (2001) 70.

[10] X.B. Zhao, G.S. Cao, C.P. Lv, L.J. Zhang, S.H. Hu, T.J. Zhu, B.C. Zhou, J. Alloy Comp. 315 (2001) 265.

[11] H. Li, X. Huang, L. Chen, Z. Wu, Y. Liang, Electrochem. SolidState Lett. 2 (1999) 547

[12] Z. Shi, M. Liu, J.L. Gole, Electrochem. Solid-State Lett. 3 (2000) 312 .

[13] Z. Liu, J.Y. Lee, J. Power Sources 97-98 (2001) 247.

[14] L.L. Garza Tovar, P.A. Connor, F. Belliard, L.M. TorresMartínez, J.T.S. Irvine, J. Power Sources 97-98 (2001) 258.

[15] M. Martos, J. Morales, L. Sánchez, R. Ayouchi, D. Leinen, F. Martin, J.R. Ramos-Barrado, Electrochim. Acta 46 (2001) 2939.

[16] R.J. Hill, A.M. Foxworthy, R.J. White, J. Power Sources 46 (1990) 171.

[17] T. Ohzuku, T. Shimamoto, T. Hirai, Electrochim. Acta 26 (1981) 751.

[18] L. Peraldo Bicelli, B. Rivolta, F. Bonino, S. Maffi, C. Malitesta, J. Power Sources 18 (1986) 63.

[19] J. Wang, P. King, R.A. Huggins, Solid State Ionics 20 (1986) 185.

[20] I. Sandu, T. Brousse, J. Santos, M. Danot, D.M. Schleich, Ionics 8 (2002) 27

[21] C. Barriga, S. Mafi, L. Peraldo-Bicelli, C. Malitesta, J. Power Sources 34 (1991) 353.

[22] W.B. Pearson, A Handbook of Lattice Spacings and Structures of Metals and Alloys, Pergamon, London, 1958, p. 717.

[23] R.A. Huggins, Ionics 3 (1997) 245.

[24] R. Ayouchi, F. Martín, J.R. Ramos-Barrado, M. Martos, J. Morales, L. Sánchez, J. Power Sources 87 (2000) 106. 